https://doi.org/10.52505/filomod.2021.15.12

\title{
ȘCOALA DE LA TÂRGOVIȘTE ȘI METAROMANUL (ÎN BAZA OPEREI „FICȚIUNE ȘI INFANTERIE” DE COSTACHE OLĂREANU)
}

\author{
Sergiu COGUT \\ Institutul de Filologie Română „B. P.-Hasdeu” al MEC
}

Rezumat: Articolul se axează pe eluicidarea uneia dintre trăsăturile dominante ale grupării de scriitori ce este cunoscută ca „școala de la Târgoviște” și anume predilecția membrilor ei pentru valorificarea metaromanului și astfel cultivarea unei proze autoreferențiale. Una dintre creațiile reprezentative în acest sens este romanul Ficțiune și infanterie de Costache Olăreanu publicat în 1980 și care poate fi considerat una dintre primele scrieri postmoderne din literatura română, fiind calificat ca un manual al tehnicilor și trucurilor textualiste, anticipând astfel proza optzeciștilor. Prin intermediul acestei opere autorul denunță impostura protagonistului său Victor Testiban ce pretinde a fi un romancier realist, dar în realitate nu este.

Cuvinte cheie: școală, proză autoreferențială, metaroman, impostură, romancier realist.

Abstract: The article focuses on the elucidation of one of the dominant features of the group of writers known as ", the Târgoviște school”, namely the predilection of its members for the valorization of the metanovel and thus the cultivation of a self-referential prose. One of the representative creations in this sense is the novel Ficțiune și infanterie (Fiction and infantry) by Costache Olăreanu published in 1980 which can be considered one of the first postmodern writings in Romanian literature, being qualified as a handbook of textualist techniques and tricks, thus anticipating the prose of the eighties. Through this work the author denounces the imposture of his protagonist Victor Testiban who claims to be a realistic novelist, but in reality he is not.

Keywords: school, self-referential prose, metanovel, imposture, realistic novelist.

Școala de la Târgoviște, așa cum au relevat criticii și istoricii literari ce au scris despre ea, a fost precursoarea postmodernismului în literatura română pe filiera lui experimentală. Astfel, Liliana Truță în monografia sa Experimentalism şi antropocentrism în proza postmodernă românească remarcă: „Direcția prozei textualiste, credem noi, reprezintă latura experimentală a postmodernismului românesc, o formă deschisă, dinamică, ce funcționează în optzecism, precedată de proza târgoviștenilor (mai ales Costache Olăreanu și M. H. Simionescu) și de cea oniric-textualistă a lui Dumitru Țepeneag" (Truță, 2010, p. 38). Cercetătorul literar Marian Victor 
Buciu, la rândul său, precizează că, spre deosebire de „onirici”, târgoviștenii „n-au fost interziși”, specificând: „Principiile lor n-au autonomie. Ele sunt bricolate. Interferează cu principiile mai multor poetici, chiar și cu cele ale onirismului estetic" (Buciu, 2010, p. 310). Dar cum a apărut gruparea de scriitori târgovișteni? Acad. Mihai Cimpoi, în studiul său monografic despre aceasta, intitulat Anatomia Ființei. Școala literară și artistică de la Târgoviște, reliefează următoarele: „Cei «grupați» au o vocație indiscutabilă a des-grupării, respectând o conditio sine qua non: libertatea, «intrarea în horă» conform unor predispoziții naturale de joc. Vânturile făcute nu urmează o direcție înafară, ci înăuntru, fiind anabazice. E o școală prin ea însăși, fără a se modela după influențe exterioare. Își este, astfel, sie însuși model. Ei se joacă, recurg la glume, scriu misive amicale, asemănându-se cu cei din «Arzamas»-ul rus, care se dedau unor acțiuni de bufonadă ritualică precum conaționalii lor de la «Junimea», fixați de Eminescu în Antropomorfism. Prin joc și prietenie se întemeiază Școala de la Târgoviște" (Cimpoi, 2014, p. 47). In anul 1942, remarcă autorii antologiei 60+1 romane românești, „Mircea Horia Simionescu îl cunoaște pe Radu Petrescu cu care formează «nucleul» Școlii de la Târgoviște. Din 1944 lor li se alătură Costache Olăreanu. Cei trei hotărăsc să nu publice nicio carte până la vârsta de 40 de ani, dar continuă să scrie, să citească și să învețe despre literatură (toți au fost studenții lui G. Călinescu)" (Cîrciu, Băltin, 2007, p. 224). Despre acest angajament, Costache Olăreanu precizează în cartea sa Poezie și autobiografie. Micul Paris că ,el nu a fost prea explicit, adică nu ne-am adunat noi, cei de la Târgoviște, şi am decretat acest lucru. Nu, categoric! Dar în discuţiile noastre, nu o dată pline de patimă și năduf, ajungeam invariabil la aceeași și aceeași concluzie: cu «ăștia» nu se poate face nimic, literatura care se cere e atât de departe de ce încercam noi să facem că nu există cale de coexistenţă. N-am înţeles și n-am acceptat în nici un fel «colaboraţionismul» unor autori (...): un Geo Bogza, un M.R. Paraschivescu, un Cicerone Theodorescu" (Olăreanu, 1994, p. 68).

Marian Popa în a sa Istorie a literaturii române de azi pe mâine remarcă în legătură cu membrii respectivei școli: „Acești domni cultivați și foarte bine crescuți se joacă de-a literatura făcând literatură fără a zdruncina ceva esențial din ei și din mediu, într-un confort deplin, împotriva unei realităţi cotidiene tot mai sumbre, dar și împotriva exigențelor oficiale privind funcția politică a scrisului; tertipurile lor narative amintesc de Sterne, de Diderot, de unii romantici germani, de unamunism și de pirandellism, totul asezonat cu unele incursiuni în nouveauromanesc" (Popa, 2009, p. 903).

Liliana Truță în studiul său relevă anumite diferențe dintre exponenții acestei școli. Astfel, în legătură cu Costache Olăreanu, ea precizează: „imaginația scriitorului nu se înscrie în estetica barocă a prolificului ostentativ și seducător din prozele lui Mircea Horia Simionescu. Din contră, prozatorul pare a sluji o estetică a conciziunii, în care esențializarea devine procedeu activ” ca, în continuare, să evidențieze: „Estetizarea pe care o întâlnim ca dominantă la toți scriitorii târgovișteni se materializează la fiecare dintre ei în direcții diferite. În cazul lui Radu Petrescu ea slujește în permanență un cult al formei desăvârșite, al suprafețelor textului regizate pictural, la Mircea Horia 
Simionescu e prezentă în simfoniile baroc organizate după principii muzicale, iar la Costache Olăreanu echilibrul se asigură pe spații mici, într-o estetică a rafinamentului conciziunii” (Truță, 2010, p. 181). La rândul său, cercetătoarea Florina Pîrjol în Carte de identități subliniază particularitatea lui Costache Olăreanu a de a fi ,«miniaturistul» grupului, umoristul cu temperament jovial moldovenesc, care scrie, în descendența lui Jules Renard, mici volume în care notează sprinten, telegrafic, imagini, senzații, portrete executate în tușe rapide, întâmplări cu iz autobiografic, impresii de lectură" (Pîrjol, 2014, p. 84-85), specificând totodată: „, El este, de fapt, cel mai «autoficțional» dintre toți târgoviștenii (dacă admitem că termenul denumește, totuși, o ficțiunede-sine, nu doar o «scriere-de-sine», ca în cazul lui Radu Petrescu). Luăm termenul francez cu ghilimelele de rigoare, pentru că, departe de încărcătura ideologică și colorat identitară, dar și de fragilitatea generică a autoficțiunii, literatura târgovișteanului poate fi descrisă mai curând ca un tip particular de fictiune auctorială, ambivalentă - e drept - sub aspectul modului de lectură" (Pîrjol, 2014, p. 85). Dar pot fi relevate și trăsături comune acestor prozatori, una dintre ele constituind-o predilecția pentru metaroman. Astfel, acad. Eugen Simion, scriind despre creația romanescă a lui Mircea Horia Simionescu în volumul IV al lucrării sale sintetice Scriitori români de azi, menționează: „romanul însuși, fiind tot mai puțin o metaforă a lumii, tinde să devină o teorie a romanului” (Simion, 2020, p. 371) și, în cazul acestui prozator, „romanul narează de regulă modul în care un personaj (naratorul) scrie un roman în care ficțiunea se amestecă și se confundă cu existența într-o succesiune năucitoare pentru cititor. Un procedeu pe care îl folosește și Costache Olăreanu și îl imită mulți alții. Ideile lui M. H. Simionescu despre epica modernă merg în sensul metaromanului sau al romanului autoreferențial. Ele s-ar putea rezuma în chipul următor: spre deosebire de scriitorul tradițional care dă o cronologie liniară a evenimentelor și vorbește limpede despre gândurile, trăirile individului, scriitorul modern pune o mare inventivitate în a descoperi procedee tehnice în așa chip încât «să ascundă intențiile și să dejoace tendința de continuitate mecanică a expresiei»; cititorul este atras în această aventură și rolul lui este de «dispecer și limpezitor al lucrurilor»; romanul are ambiția să facă «inventarul complet al tuturor situațiilor și obiectelor universului», romanul nu poate fi decât o parodie a altui roman și, în genere, cine zice roman zice spirit polemic, iar orice roman propune fără voia lui «o altă rețetă de roman»" (Simion, 2020, p. 372). Totodată, merită remarcat că și acad. Mihai Cimpoi în Argument-ul cu care începe recent publicatul său studiu monografic despre Radu Petrescu menționează că acest scriitor „,deschide un laborator de creație sui-generis, în cadrul căruia se proiectează și se realizează afectiv noi forme de roman care nu se opune celei tradiționale, ci o înnoiește sub îndemnul Sfântului Augustin ales ca motto la Didactica nova: A vedea în cerul nou și pământul nou (Videatur in caelo novo et in terra nova).

Apare exercițiul de roman ( $O$ moarte în provincie, rămas inedit), protoromanul și meta-romanul (identificabile în $O$ singură vârstă, în Ce se vede și Sinuciderea din Grădina Botanică) (...). Radu Petrescu ilustrează momentul de răscruce în evoluția literaturii române, când romanele încep să 
vorbească despre romane, despre modul de a reprezenta și a da formă și sens experienței" (Cimpoi, 2019, p. 8-9).

Unul dintre metaromanele scrise de membrii școlii de la Târgoviște, publicat în 1980, asupra căruia ne vom opri în continuare este Ficțiune și infanterie de Costache Olăreanu. În prefața sa la această operă a prozatorului născut la Huși, C. Stănescu precizează: „Autorul de pe copertă, Costache Olăreanu, îl împinge pe scriitorul Victor Testiban în aventura scrierii unui meta-roman: romanul care nu mai reprezintă viața, ci însăși scrierea romanului. Ficțiune și infanterie este, de aceea, și una dintre primele noastre scrieri postmoderne, un manual al tehnicilor și trucurilor textualiste pentru care, în treacăt fie spus, prozatorii optzeciști pot fi invidioși” (Olăreanu, 2005, p. 8). Iar tânărul cercetător literar Mihai Iovănel în recent publicata sa Istorie a literaturii române contemporane: 1990-2020, referindu-se la Ficțiune și infanterie, menționează că „,este un metaroman à la André Gide din Paludes având ca pretext pierderea unui manuscris și ca subiect imposibilitatea autorului de a-1 reconstitui. Romancierul Victor Testiban asistă la fărâmițarea, în ceea ce ține de convenție și artificiu, a ficțiunii pe care o imaginase, concomitent cu trecerea ei în actele de stare civilă, adică în realitate. Un proces care inversează ironic, epuizându-l, visul lui Balzac de a concura starea civilă" (Iovănel, 2021, p. 356). La rândul său, Marian Popa în Istoria... lui la care ne-am referit deja consideră această operă cel mai bine realizat dintre romanele scriitorului, remarcând despre protagonist că „viața sa personală și aceea de creator sunt combinate și confruntate în încercarea de reconstituire a romanului, creându-se astfel ocazii variate pentru jocuri de intervertire a realului și ficționalului, identificabile și operabile unde nu ar trebui să fie și inexistente sau irelevante unde le-ar fi locurile" (Popa, 2009, p. 911). Iar Lina Codreanu, în monografia ce i-a consacrat-o lui Costache Olăreanu, reliefează importanța acestui roman, menționând că pentru literatura contemporană, el „,rămâne o scriere de pionierat atât prin substanța inedită, precum și, îndeosebi, prin tehnica narativă novatoare în estetica romanului", precizând totodată: „Aici, un romancier - Victor Testiban - întocmește scheme, profilează personaje, stabilește repere cronotopice, dar pierde firul epic, personajele nu-1 ascultă și, în zbaterea de a reconstitui conţinutul unui manuscript pierdut, întâmplările nu se încheagă într-o proză coerentă" (Codreanu, 2019, p. 148). Interesant este că și în creația lui Mircea Horia Simionescu, așa cum relevă Eugen Simion, confesiunea din opera acestuia Toxicologia sau Dincolo de bine și dincoace de rău cuprinde „un mic roman fals picaresc sau, mai bine zis, voit și livresc picaresc, Intoarcerea fiului risipitor, scris, în prima variantă (după mărturiile aduse de Helga și Cella) în 1953. Cartea ar fi fost pierdută în troleibuzul 82 și numai două fragmente, trimise în copie prietenului Radu Petrescu, s-au păstrat. O ficțiune, probabil, și aceasta” (Simion, 2020, p. 366). Iar cu referire la romanul lui C. Olăreanu, ilustrul critic, în aceeași lucrare, menționează că autorul „folosește toate schemele prozei autoreferențiale, dar într-un chip special: povestindu-le. (...) El nu scrie atât despre felul în care se scrie un roman, scrie istoria unui autor care încearcă să compună un roman și nu reușește. Istoria are haz, fantezia prozatorului este remarcabilă" 
(Simion, 2020, pp. 397-398). Totodată, academicianul român amintește că Ov. S. Crohmălniceanu remarcă (...) imaginația ludică a romanului și indică un posibil model: Le vol d'Icare de Queneau”, în continuare reliefând: „Ficțiune și infanterie cuprinde, în fapt, trei rânduri de istorii: (a) istoria reconstituirii unui roman pierdut, (b) fragmente din manuscrisul reconstituit și (c) reflecțiile naratorului (Victor Testiban) și ale prietenului său, psihologul Safiu, despre romanul auctorial și romanul heterodox... În prima categorie de fapte intră și o cronică a existenței naratorului (Victor Testiban) care se încrucișează cu cealaltă cronică (a scriiturii)" ( Simion, 2020, p. 398). În același context, Lina Codreanu precizează: „Prin tehnica colajului sunt aplicate în rama viitoarei cărți pagini refăcute ale manuscrisului, ceea ce triplează inserțiile, fiindcă o primă ramă ar fi relatarea avocatului pensionar Panaitescu despre trudnicile căutări ale noii sale cunoștințe - Victor N. Testiban; apoi, în căptușeala epică intră relațiile perdantului cu abilul George Condeescu (nume predestinat), Aurel Safiu ori cu Filimon. În ultimul rând, narațiunea interioară include paginile reconstituite, necoagulate, reușite monovalent fie prin schematice relații de cuplu și flirturi ale personajelor, fie prin monolog interior, fie prin pasaje descriptive alternate cu gânduri risipite etc." (Codreanu, 2019, p. 149-150).

Idealul scriitorului Testiban este romanul obiectiv, altfel spus, romanul tradițional, auctorial, astfel că el se confesează prietenului său Safiu: „Vreau să scriu un roman limpede, clar, bine construit, cu personaje firești, cu o acțiune închegată, logică”. Și, la remarca interlocutorului său despre secolul în care a înflorit acest roman, încuviințează: ,-- Fie și ca-n secolul XIX” (Olăreanu, 2005, p. 134). Apoi el respinge romanul contemporan pe care îl numește, cu regret, „un maidan în care arunci ce vrei și ce nu vrei” (Olăreanu, 2005, p. 135). Dar tocmai un roman de acest tip, un roman fragmentar ajunge să scrie, transformând narațiunea, așa cum precizează Eugen Simion, ,într-o debara în care introduce de toate: și fragmente din povestiri vechi, și opinii despre literatură, și fapte mărunte de existență" (Simion, 2020, p. 399), remarcând totodată: „Această discrepanță dintre aspirație și vocație este notată, evident, ironic". Dintre considerațiile protagonstului privitoare la arta literară, merită să o reproducem pe următoarea: „«Ce ușor se ajunge la realism! Dar cât de cumplit e drumul mai departe!» exclamă Testiban.

Privind cu atenție lucrurile, luându-ți foarte în serios meseria de anatomist al vieții, devii materialist, și încă unul vulgar, aproape fără să-ți dai seama. Vrând să despici, să analizezi, să nu mai rămâi la suprafața lucrurilor (descrieri oricât de frumoase, dar plate) intri în străfunduri, în moleculele bucății de zahăr, ca și în intestinele vreunui personaj, te încurci în scamele carpetei pe care doarme cotoiul ori pulverizezi pe mătușa amfitrionului (o doamnă bătrână și extrem de cumsecade) printr-o simplă rază de soare reflectată în oglindă și care o mătură pentru totdeauna. Cu cât descrii mai puțin, cu atât un obiect are mai mari șanse de supraviețuire. Cu cât îl descrii mai amănunțit, cu atât îl transformi într-un monstru (ca în repetarea aceluiași cuvânt de o sută de ori, până devine de nerecunoscut). 
Iată o sobă sau un pantof, iată o clanță sau o nevinovată ureche! Dacă scrii pe deasupra, ele vor rămâne ceea ce sunt (și aici romanul s-a putea defini ca o suprafață). Dar cum să reziști tentației de a intra măcar pentru o clipă într-un lucru, oricât de neînsemnat? Drama unui adevărat artist e că trebuie să dea deoparte toate aceste intenții și să rămână logic, pentru a fi înțeles, că ceea ce scrie el pentru public e o infimă parte din universul sfărâmat de ochiul său cercetător" (Olăreanu, 2005, p. 117). În prefața lui la roman, C. Stănescu comentează astfel acest fragment: „Scriitorul denunță impostura în care se află romancierul realist din romanul său, un roman polemic nu în afară, ci înăuntru, protagoniști fiind autorul de pe copertă și personajul din carte: realismul consecvent cu sine face realitatea de nerecunoscut, iar a duce exigența mimesis-ului până la ultimele sale consecințe înseamnă a transforma lumea în coșmar și oamenii în monștri. Stringența logică îl împinge pe creatorul realist, un «anatomist al vieții», să arunce lumea în neant: criza literaturii este criza artistului umanist, care (vrea să) scrie pentru oameni așa cum par ei să fie la suprafață și nu cum sunt în adâncimea la care ei înșiși nu pătrund. Iată conflictul irezolvabil în cleștele căruia s-a prins fără scăpare romancierul lui Costache Olăreanu" (Olăreanu, 2005, p. 9). Cu referire la romanul virtual al lui Testiban, Liliana Truță menționează, la rândul său, că acesta ,tinde să acapareze mai ales concretul fenomenal, foșnetul viu al materiei, să capteze o lume vie a detaliilor" (Truță, 2010, p. 196) și exemplifică prin următorul episod: ,... ne-am întâlnit cu o mare muscă verde. Stătea pe o creangă. N-a zburat. Poate de aceea ne-am apropiat și noi ceva mai mult ca să-i admirăm construcția desăvârșită. Ce navă admirabilă, ce miniaturizare inginerească demnă de invidiat!..." (Olăreanu, 2005, p. 96). De asemenea, cercetătoarea de peste Prut remarcă: „În paralel cu reflecțiile personajului auctorial pe marginea convențiilor legate de traditia romanului și de receptarea lui, sunt inserate și fragmente din virtualul roman pe care autorul le citește în contrapunct cu jocurile libere ale imaginației sale, acestea fiind însă cele mai autentice pagini. Metaromanul devine astfel mai viu decât textul-matrice pe care-1 parazitează, mai realist decât convenția realistă" (Truță, 2010, p. 196). Merită să evidențiem supărarea lui Testiban pe amicul său Condeescu, scriitor și el, din cauza unui titlu pe care acesta i-1 dăruise și, chiar dacă protagonistul i-a spus la telefon că a scris o sută de pagini la el, i 1-a cerut înapoi, dorind să îl folosească pentru o nouă carte. Este vorba despre Dragoste cu vorbe și copaci. Interesant este că însuși scriitorul Costache Olăreanu va publica în 1987 un roman intitulat chiar așa - Dragoste cu vorbe și copaci. Cu referire la romanul dat și la cel din 1983 Avionul de hârtie, Florina Pîrjol în lucrarea din care am citat deja precizează că cele două opere „reiau, sub forma pastișei ironic-afectuoase, modelul romanului epistolar pe care Costache Olăreanu, cu mult înaintea reprezentanților postmodernismului autohton, reușește să-1 recupereze și revigoreze" (Pîrjol, 2014, p. 87). În monografia sa despre prozatorul român, Lina Codreanu, referindu-se la Victor Testiban, recurge la conceptul de „metapersonaj” pentru a elucida specificul statutului acestuia. Astfel, în studiul său, autoarea relevă că el, ca scriitor, ,avea o identitate ștearsă, așa cum și cartea sa - un conținut confuz, de aceea eroul încearcă 
o reavivare ideală, printr-o cumpănire mai atentă a componentelor și tehnicilor de elaborare a romanului pierdut din fragmentare aduceri aminte. Ajustările au în vedere și crearea unor fișe caracterologice (Jean Lalescu, Matilda Arabolu, Ioana Manoliu, Arabolu - general, Ferdinand), ceea ce face din Testiban un metapersonaj (personaj-romancier care are în vedere creionarea propriilor personaje). In ciuda efortului, toate $i$-au devenit potrivnice și a priceput farsa abia la final, când ideea romanului pierdut/ căutat/ reinventat alunecase deja în bibliografia altcuiva" (Codreanu, 2019, p. 159).

Școala de la Târgoviște, menționăm în concluzie, se remarcă, pe lângă anumite diferențe dintre membrii săi, prin faptul că ei mizează pe estetizare și pe valorificarea metaromanului. O scriere exponențială din acest punct de vedere este Ficțiune și infanterie de Costache Olăreanu în care autorul recurge la convenția reconstituirii manuscrisului de roman pierdut, realizând astfel o operă prin intermediul căreia el denunță impostura protagonistului său Victor Testiban ce se complace ca scriitor realist improvizat.

\section{Referințe bibliografice:}

1. BUCIU, Marian Victor. $10+10$ prozatori exemplari nominalizați la Nobel. București, 2010.

2. CIMPOI, Mihai. Anatomia Ființei. Școala literară și artistică de la Târgoviște. Târgoviște, 2014. 2019.

3. CIMPOI, Mihai. Radu Petrescu flaubertianul postmodern. Eseu, Târgoviște,

4. CÎRCIU, Evelina, Băltin, Katalin. 60+1 romane românești. Brașov, 2007.

5. CODREANU, Lina. Costache Olăreanu. Arhitecturi ludice. Prefață de acad. Mihai Cimpoi, Târgoviște, 2019.

6. IOVĂNEL, Mihai. Istoria literaturii române contemporane: 1990-2020, Iași, 2021.

7. OLĂREANU, Costache. Ficțiune și infanterie. Prefață de C. Stănescu, București, 2005.

8. OLĂREANU, Costache. Poezie și autobiografie. Micul Paris, București, 1994.

9. PÎRJOL, Florina. Carte de identităti,i, București, 2014. 2009.

10. POPA, Marian. Istoria literaturii române de azi pe mâine, vol. II, București,

11. SIMION, Eugen. Scriitori români de azi, vol. IV, Iași, 2020.

12. TRUȚĂ, Liliana. Experimentalism și antropocentrism în proza postmodernă românească, Pitești, 2010.

Notă: Articolul a fost realizat în cadrul proiectului de cercetare 20.80009.1606.03 Contexte socioculturale autohtone şi interconexiuni europene în creaţia populară şi literatura cultă din Basarabia (sec. XIX până în prezent), Institutul de Filologie Română „B. P.-Hasdeu” al MEC. 